\title{
Inhibition by essential oils of Mentha viridis and Mentha pulegium (Lamiaceae) in proteolysis, fibrinogenolysis and coagulation caused by venomous snakes
}

\author{
Lucilene Fernandes Silva ${ }^{1}$, Mariana Aparecida Braga ${ }^{2}$, Mariana Araújo Espósito², Pedro \\ Henrique Souza Cesar ${ }^{2} \&$ Silvana Marcussi ${ }^{2 *}$ \\ 1. Department of Chemistry, Organic Chemistry Laboratory, Universidade Federal de Lavras (UFLA), Campus \\ Universitario, Lavras, Minas Gerais, 37200-000, Brazil. \\ 2. Department of Chemistry, Biochemistry Laboratory, Universidade Federal de Lavras (UFLA), Campus Universitario, \\ Lavras, Minas Gerais, 37200-000, Brazil; marcussi@dqi.ufla.br \\ * Correspondence
}

Received 22-X-2018. C Corrected 12-III-2019. Accepted 31-VII-2019.

\begin{abstract}
Snake venoms are widely used as laboratory tools for studies of physiological, pharmacological and toxicological mechanisms. Venoms used here are rich sources of several classes of proteases that act on factors of the coagulation cascade, fibrinogenolysis and fibrinolysis, altering the hemostatic processes, and phospholipases $A_{2}$ which are involved mainly in inflammatory and clotting processes. Natural products such as essential oils are made up of active ingredients with wide application in the food, pharmaceutical and cosmetic industries. Thus, this study evaluates the essential oils from Mentha viridis and Mentha pulegium on coagulation, fibrinogenolysis and degradation of azocasein, induced by Bothrops sp and Lachesis muta muta venoms. These oils were achieved by hydrodistillation and presented, respectively, as the main constituents linalool (40.70\%), carvone (13.52\%) and $\alpha$-terpinene (8.56\%); pulegone (50.01\%), menthol (31.90\%) and menthone (16.56\%). The essential oils were previously incubated with Bothrops alternatus venom, for two different times, then plasma was added and time was recorded. The $M$. viridis oil presented greater anticlotting potential. Meanwhile, the M. pulegium oil presented anticlotting or proclotting activity dependent on the dose tested. The incubation time also influenced the effect of the oils on the coagulation time. At azocaseinolytic assay, the oil from M. pulegium reduced the activity for all evaluated venoms. The highest inhibition was of $39.99 \%$; on activity induced by $B$. jararacussu, $M$. viridis reduced the activity in $57.72 \%$. On B. moojeni, the major inhibition observed was of $74.67 \%$. The fibrinogenolysis induced by $B$. moojeni venom was totally inhibited by both oils in the evaluated proportions. The results show the presence in oils of protease inhibitors, considering serine and metalloproteases (acting on clotting factors or with hemorrhagic activity), as well as phospholipase $\mathrm{A}_{2}$ (enzymes involved in inflammation and clotting processes) inhibitors of wide application in medical and biotechnology areas.
\end{abstract}

Key words: Bothrops; Lachesis; protease inhibition; essential oil; natural compounds; antiophidian properties.

Fernandes Silva, L., Aparecida Braga, M., Araújo Espósito, M., Souza Cesar, P. H., \& Marcussi, S. (2019). Inhibition by essential oils of Mentha viridis and Mentha pulegium (Lamiaceae) in proteolysis, fibrinogenolysis and coagulation caused by venomous snakes. Revista de Biología Tropical, 67(4), 999-1009.

Essential oils are described as a complex mixture of volatile substances with oily consistency resulting from plant secondary metabolism (Simões et al., 2007). Bandoni and Czepak
(2008) found that the chemical composition of essential oils is changed by varying the proportions of their constituents or by transforming one constituent into another. These changes 
occur according to the chemotype, environmental factors and also with the development of the plant.

According to Bakkali, Averbeck, Averbeck, and Idaomar (2008) the major constituents of essential oils may be responsible for biological activity; however, the action of essential oils can also be attributed to the synergistic or antagonistic action of their different components. The plant species that constitute the genus Mentha, belonging to the Lamiaceae family (Dimitri, 1980) are widely cultivated on five continents, especially in the temperate and sub-temperate regions of the world (Wang, Yu, Liu, Liang, \& Li, 2013).

The essential oils from species of the genus Mentha have a high commercial value, because they present the monoterpene menthol in its constitutions, being this compound widely used in the pharmaceutical, cosmetic, personal hygiene and food industries (Khanuja, Shasany, Srivastava, \& Kumar, 2000; Santos, Schneider, Bizzo, \& Deschamps, 2012). In this perspective the evaluation of the essential oils as to their effects on the proteases and phospholipases $A_{2}$ that act in the processes like blood coagulation, inflammation and fibrinogenolysis, as well as their direct action on the blood clotting cascade, would increase the knowledge of these natural products and direct them to new commercial applications.

Snake venoms are complex mixtures which $95 \%$ of the dry weight are protein components mainly represented by enzymes (e.g. proteases, phospholipases and L-amino acid oxidases) (Matsui, Fujimura, \& Titani, 2000). Snake venoms present a variety of pharmacologically active substances, which induce pronounced effects such as inflammation and changes in hemostasis (Gutiérrez \& Rucavado, 2000).

Snake venom proteases can act by breaking on different protein substrates such as components of cell membranes, blood and tissues proteins and those that make up the basal lamina (Markland, 1998; Baldo et al., 2010). Other studies also report the action of metalloproteases and phospholipases on cells and molecules that integrate the hemostatic system
(Escalante, Rucavado, Fox, \& Gutiérrez, 2011; Bernardoni et al., 2014; Sharon, Trabi, \& Richards, 2016), as well as the mechanisms by which these classes of toxins act in the blood coagulation cascade. Some proteases act on factors V, VIII, IX, X, XIII, prothrombin, fibrinogen and/or fibrin, altering the fibrin formation and fibrinogenolysis processes (Takeda, Takeya, \& Iwanaga, 2012). Phospholipases $\mathrm{A}_{2}$ have also been described with direct action on factors II, VII, X of the coagulation cascade, or with indirect action on the coagulation process once their catalytic action result in the generation of lysophospholipids (Sajevic, Leonardi, \& Krizaj, 2011).

Brazilian folk medicine is very rich in the description and use of plants to combat the various effects caused by ophidian accidents (Marcussi et al., 2007; Carvalho et al., 2013; Guimarães et al., 2014). Considering the wide variety of catalytic and toxic-pharmacological activities carried out by venoms, numerous studies have made use of these and their isolated toxins as laboratory tools of great value in the scientific field. These tools have in vivo, in vitro and in silico application to evaluate the action of inhibitors, mainly natural ones, prospecting their possible effects on enzymes, homologous to those of venoms, present in animal organisms, including humans (EstêvãoCosta, Diniz, Magalhães, Markland, \& Sanchez, 2000; McCleary \& Kini, 2013).

However, scientific studies that explore the pharmacological properties of plant compounds are poor in discussions about the action mechanisms of these enzymatic inhibitors, especially on human proteases and phospholipases, involved in digestion processes, cell death, tissue regeneration, inflammation and several other processes of great relevance in the development and treatment of pathologies. In this context, the aim of the present study was to characterize the essential oils of Mentha viridis L. and Mentha pulegium L. through protease and phospholipase inhibition assays, as well as inhibiting blood plasma coagulation, using $\mathrm{CaCl}_{2}$ or venom to induce the formation of the clot. 


\section{MATERIALS AND METHODS}

Collection and identification of plants: Mentha viridis and Mentha pulegium leaves samples were collected in the Federal University of Lavras - UFLA on a mild day without precipitation. The plants were identified and incorporated into the collection of the ESAL Herbarium in the Department of Biology of UFLA - MG, under the registration numbers 27122 (M. pulegium L.) and 27123 (M. viridis L.).

Extraction of essential oil: The extractions were performed with $150 \mathrm{~g}$ of each plant species for $3 \mathrm{~L}$ of water. Leaves of the two Mentha species were weighed and submitted to hydrodistillation process in a modified Clevenger apparatus, adapted to a $6 \mathrm{~L}$ round bottom flask, for $2 \mathrm{~h}$, to obtain the hydrolate. The hydrolate was centrifuged at $965.36 \mathrm{~g}$ for $10 \mathrm{~min}$. The essential oil was collected (3.81 $\mathrm{ml}$ of $M$. pulegium oil and $2.28 \mathrm{ml}$ of $M$. viridis oil) and stored at $12{ }^{\circ} \mathrm{C}$, protected from light (ANVISA, 2010). The extraction of the essential oils was done in triplicate. The yield for the essential oils of $M$. pulegium and $M$. viridis were $2.54 \%$ and $1.52 \%$, respectively, on a moisture free basis. The chemical characterization of the essential oils of $M$. viridis and $M$. pulegium was previously published by Silva et al. (2015).

Snake venoms: The crystalline crude venoms were commercially purchased from the serpentarium Bioagents (Batatais-SP). The venoms were weighed and dissolved in phosphate buffered saline (PBS, $\mathrm{pH}$ 7.4).

Human Blood for clotting assays: The peripheral blood from three volunteers $(10 \mathrm{ml}$ of each volunteer) was used after free informed consent; the volunteers did not present disease symptoms and reported not having used prescription drugs for at least 30 days prior to collection. The volunteers' plasma was obtained by centrifugation and mixed to obtain a pool, used in the assays. This study was approved by the Committee of Ethics in Research with Humans of UFLA and filed under the number 17935713.8.0000.5148.

Effects on clotting: To induce clot formation, a calcium chloride solution $\left(\mathrm{CaCl}_{2}\right), 50 \mu \mathrm{l}$ at $100 \mathrm{mM}$, previously standardized as minimum clotting dose (responsible for inducing coagulation of $200 \mu \mathrm{L}$ of citrated plasma in a time interval between 3 and $5 \mathrm{~min}$ ) and $0.4 \mu \mathrm{g}$ of Bothrops alternatus venom, previously standardized as minimum clotting dose, were used.

The coagulation assay was performed according to Mourão et al. (1996), with modifications. For the assay with $\mathrm{CaCl}_{2}$ the essential oils from M. pulegium and M. viridis (0.15; $0.30 ; 0.60 ; 1.2 ; 2.4 \mu \mathrm{l})$ were incubated with $\mathrm{CaCl}_{2}$ for $5,10,15,20$ or 30 minutes at $37^{\circ} \mathrm{C}$, with subsequent addition of citrated plasma or incubated with the plasma with subsequent addition of $\mathrm{CaCl}_{2}$.

For B. alternatus venom coagulation assay, the essential oil from $M$. pulegium or $M$. viridis and PBS in the same volumes were submitted to previous incubations under the same conditions with the $B$. alternatus venom or citrated plasma. Controls containing only plasma + $\mathrm{CaCl}_{2}$, plasma + essential oil and plasma + venom were performed. The reactions were timed and the results presented in minutes that preceded the formation of a rigid clot.

\section{Proteolytic activity on azocasein:}

Solid medium: The proteolytic activity in solid medium was evaluated according to Gutiérrez, Avila, Rojas, and Cerdas (1988). The medium was prepared with incorporation of the azocasein, adapting concentrations described by Markland (1998) for evaluation of the caseinolytic activity in liquid medium, as described by Oliveira, Simão, Trento, César, and Marcussi (2016).

The azocasein was dissolved in Tris- $\mathrm{HCl}$ ( $\mathrm{pH}$ 9.6), under slight agitation and, added to the medium at $45^{\circ} \mathrm{C}$. Samples of the essential oils of M. pulegium and M. viridis $(0.60,1.2$, 2.4, and $4.8 \mu \mathrm{l})$ were preincubated at $37{ }^{\circ} \mathrm{C}$ for 15 min with B. jararacussu, B. moojeni, 
B. alternatus or Lachesis muta muta venoms. The azocaseinolytic activity was quantified by measuring the diameter of the halos formed in the medium.

Liquid medium: The proteolytic activity in liquid medium was evaluated according to Markland (1998). Different volumes of $M$. pulegium and $M$. viridis essential oils (0.6 and $1.2 \mu \mathrm{l})$ were incubated with $50 \mu \mathrm{g}$ of the $B$. jararacussu or B. moojeni venoms and $100 \mu \mathrm{g}$ of the B. alternatus or L. muta muta venoms. Incubation volumes were completed to $200 \mu \mathrm{l}$ with $50 \mathrm{mM}$ Tris-HCl. Samples remained at $37{ }^{\circ} \mathrm{C}$ for $15 \mathrm{~min}$, then the casein solution was added and a new incubation was performed for more 30 minutes. Acetic acid $50 \%$ was added to interrupt enzymatic activity, the samples were centrifuged at $900 \mathrm{~g}$ for $10 \mathrm{~min}$ and the solutions supernatant were read at $450 \mathrm{~nm}$. A unit of azocaseinolytic activity corresponds to an increase of 0.001 in absorbance measured at $450 \mathrm{~nm}$ under the reaction conditions defined by the method.

Fibrinogenolytic activity: For this activity, the essential oils from M. pulegium and $M$. viridis in the volume of $0.60 \mu \mathrm{l}$ were incubated with bovine fibrinogen $(60 \mu \mathrm{g})$ at the times of 5,15 , and $30 \mathrm{~min}$. The same volume of oils and incubation times were also used to previous incubations with $B$. moojeni or L. muta muta $(40 \mu \mathrm{g})$ venoms (30 $\mathrm{min})$ with subsequent addition of fibrinogen and incubation for another $2 \mathrm{~h}$ at $37^{\circ} \mathrm{C}$.

Reactions were stopped by the addition of $5 \mu \mathrm{l}$ of bromophenol blue solution [0.05 $\mathrm{M}$ Tris- $\mathrm{HCl}, \mathrm{pH} 8.0$, containing $10 \%(\mathrm{v} / \mathrm{v})$ glycerol, $10 \%$ (v/v) mercaptoethanol, $2 \%$ $(\mathrm{w} / \mathrm{v})$ sodium dodecyl sulfate (SDS) and 0.05 $\%(\mathrm{w} / \mathrm{v})$ bromophenol blue] and incubation in boiling bath for $5 \mathrm{~min}$. The samples were analyzed by electrophoresis in $12 \%$ polyacrylamide gel in the presence of SDS (SDSPAGE). Controls containing only fibrinogen were also performed.

Possible interactions between the molecules present in the essential oils and fibrinogen were considered through the test with pre-incubation of bovine fibrinogen $(60 \mu \mathrm{g})$ and essential oils $(0.60 \mu \mathrm{l})$ for different times. On the other hand, the inhibitory potential of oils on the fibrinogenolytic enzymes present in the venoms was also evaluated with subsequent addition of each venom (L. muta muta and B. moojeni).

Statistical Analysis: The results were presented as the mean of the triplicates \pm standard deviation obtained in three independent assays. The significance of the difference between the means was determined by the analysis of variance, followed by Tukey's test when the treatments were compared with the control (R Core Team, 2012). The results were considered statistically significant when $\mathrm{P}<0.05$.

\section{RESULTS}

Incubation of the essential oil of M. pulegium with $\mathrm{CaCl}_{2}$ proceeding with subsequent addition of the plasma (Fig. 1A) resulted in an increase in coagulation time mainly for the oil volume of $1.2 \mu \mathrm{l}$. However, M. viridis oil, in all evaluated volumes, induced a reduction in coagulation time reaching values lower than the control, performed only with $\mathrm{CaCl}_{2}$, presenting pro-clotting effect (Fig. 1A).

Another assay was carried out by incubating the essential oils of $M$. pulegium and $M$. viridis $(0.15,0.30,0.60,1.2$, and $2.4 \mu \mathrm{l})$ with plasma for $5 \mathrm{~min}$, followed by addition of $\mathrm{CaCl}_{2}$. In the presence of $M$. pulegium oil, an increase in the coagulation time was observed, characterizing anticoagulant activity. However, a decrease in the coagulation time was observed to $M$. viridis oil, when compared to the control containing only $\mathrm{CaCl}_{2}$, characterizing pro-clotting activity.

To verify the potential of the essential oils in altering the coagulant activity induced by proteases present in the B. alternatus venom, tests were also carried out with previous incubation (10 and $20 \mathrm{~min})$ of oils $(0.15,0.30,0$, $60,1.2$, and $2.4 \mu \mathrm{l})$ with the venom $(5 \mu \mathrm{g})$, proceeding with plasma addition and timing. At $10 \mathrm{~min}$ incubation time, M. pulegium and $M$. viridis oils in the volume of $0.30 \mu \mathrm{l}$ 
presented a greater anticoagulant potential, while in the volume of $0.15 \mu \mathrm{l}, M$. pulegium oil showed pro-clotting effects (Fig. 1C). It was also verified in this assay that larger volumes of essential oils $(0.60,1.2$, and $2.4 \mu \mathrm{l})$ resulted in pro-clotting activity, with coagulation times lower than the control containing only venom (data not shown). For 20 min incubation time, M. pulegium oil presented anticoagulant activity in the volumes of 0.15 and $0.30 \mu \mathrm{l}$ (Fig. 1C).

The incubation of the essential oil of $M$. viridis with the $B$. alternatus venom and subsequent addition of the plasma resulted in anticoagulant activity for all volumes and times evaluated (Fig. 1D). For 20 min time (Fig. 1D), the essential oil of $M$. viridis in the volumes of 0.15 and $0.30 \mu \mathrm{l}$ did not show values of anticoagulant activity statistically different from the values observed for the time of $10 \mathrm{~min}$.

The oil of M. pulegium demonstrated to be pro-clotting only in the volume of $0.15 \mu \mathrm{l}$, after 10 min of incubation with $B$. alternatus venom (Fig. 1C). Meanwhile, the essential oil from $M$. viridis presented pro-clotting action when incubated with $\mathrm{CaCl}_{2}$ or citrated plasma and anticoagulant action when previously incubated with B. alternatus venom (Fig. 1D).

The effects of essential oils were evaluated on the azocaseinolytic activity by preincubation with different venoms (B. jararacussu, B. moojeni, B. alternatus and Lachesis muta muta), before the addition of the protein substrate (Table 1).

In the proteolytic activity on azocasein in liquid medium, essential oil from M. pulegium induced reduction in activity exerted by all the venoms (B. jararacussu, B. moojeni, B. alternatus and L. muta), except for $0.6 \mu \mathrm{l}$ of oil incubated with $B$. moojeni venom (Table 1). The highest inhibitions were obtained on $B$. jararacussu venom with $34.33 \%$ and $39.99 \%$ inhibition for 0.6 and $1.2 \mu \mathrm{l}$ volume, respectively. The higher volumes $(2.4$ and $4.8 \mu \mathrm{l})$ could not be evaluated in liquid medium, since resulted in changes in spectrophotometric analysis.

$M$. viridis essential oils $(0.6$ and $1.2 \mu \mathrm{l})$ reduced the azocaseinolytic activity induced by $B$. jararacussu venom, in $40.93 \%$ and $57.72 \%$, respectively. On B. moojeni venom, the same volumes were responsible for inhibitions of $74.67 \%$ and $47.4 \%$, respectively. However, for B. alternatus and L. muta venoms, activity evaluation in liquid medium resulted in potentiation of substrate breakage, with activity increased between $20.84 \%$ and $54.61 \%$ (Table 1 ).

In the azocaseinolytic activity in solid medium, $100 \%$ inhibition of the activity induced by $B$. jararacussu, B. moojeni and $L$. muta venoms was obtained utilizing the essential oil from M. pulegium (2.4 and $4.8 \mu \mathrm{l})$. The essential oil from $M$. viridis $(2.4$ and $4.8 \mu \mathrm{l})$ completely inhibited the activity induced by B. moojeni, B. alternatus and L. muta venoms (Table 2). For smaller volume of $M$. pulegium oil the greatest inhibitions were observed on the activity induced by B. moojeni $(27.27 \%)$ and B. jararacussu (20.83\%) (Table 2).

Values obtained to the venoms correspond to $100 \%$ of activity. The data represent mean

TABLE 1

Effect of essential oils from Mentha pulegium and Mentha viridis on azocaseinolytic activity, induced by snake venoms, in liquid medium

\begin{tabular}{cccccc}
\multicolumn{2}{c}{$\begin{array}{c}\text { Essential oil } \\
(\mu \mathrm{l})\end{array}$} & B. jararacussu $\left(50 \mu \mathrm{g} \mathrm{ml}^{-1}\right)$ & B. moojeni $\left(50 \mu \mathrm{g} \mathrm{ml}^{-1}\right)$ & B. alternatus $\left(100 \mu \mathrm{g} \mathrm{ml}^{-1}\right)$ & L. muta muta $\left(100 \mu \mathrm{g} \mathrm{m} l^{-1}\right)$ \\
M. pulegium & 0.6 & $65.67 \pm 0.04^{*}$ & $103.24 \pm 0.13$ & $66.61 \pm 0.08^{*}$ & $84.53 \pm 0.02^{*}$ \\
& 1.2 & $60.01 \pm 0.02^{*}$ & $84.35 \pm 0.03^{*}$ & $73.07 \pm 0.16^{*}$ & $79.38 \pm 0.07^{*}$ \\
M. viridis & 0.6 & $59.07 \pm 0.13^{*}$ & $25.33 \pm 0.11^{*}$ & $144.0 \pm 0.04^{*}$ & $120.84 \pm 0.14^{*}$ \\
& 1.2 & $46.28 \pm 0.08^{*}$ & $52.60 \pm 0.12^{*}$ & $154.61 \pm 0.15^{*}$ & $120.93 \pm 0.07^{*}$ \\
\hline
\end{tabular}

Values obtained to the venoms correspond to $100 \%$ of activity. The data represent mean and standard derivation of analyses done in triplicate. $*$ Differ statistically from the positive control at $5 \%$ of significance. 

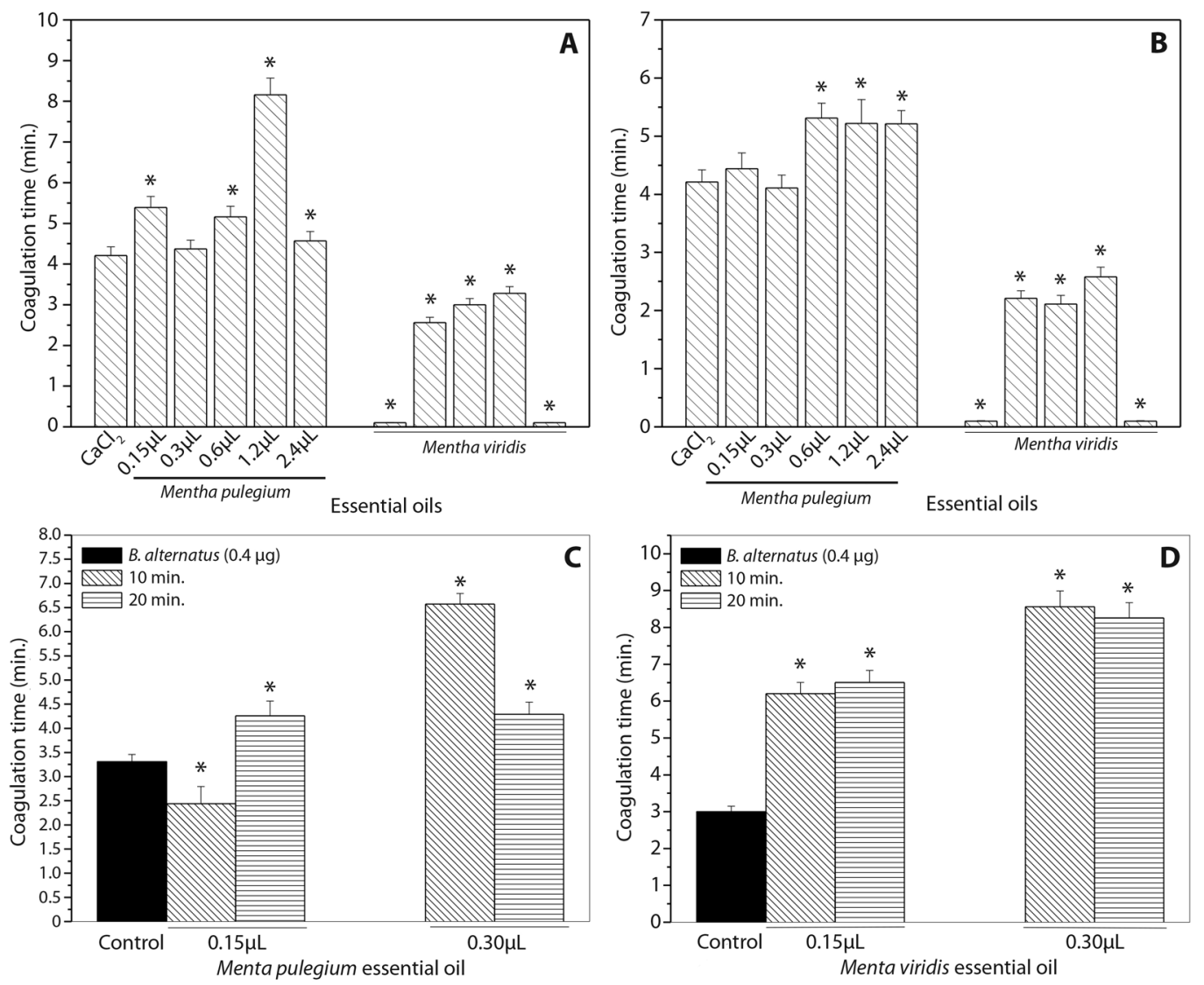

Fig. 1. Effect of essential oils on the coagulation of human plasma induced by calcium chloride $\left(\mathrm{CaCl}_{2}\right)$. (A) Previous incubation of different volumes of essential oils with calcium chloride $(5 \mathrm{~min}$.) followed by addition of the citrated human plasma at $37^{\circ} \mathrm{C}$ and timing. (B) Previous incubation of different volumes of essential oils with citrated human plasma followed by addition of the calcium chloride $\left(5 \mathrm{~min}\right.$.) at $37^{\circ} \mathrm{C}$ and timing. Effect of essential oils on the coagulation of human plasma induced by Bothrops alternatus. (C) Previous incubation of different volumes of essential oil from Mentha pulegium with $B$. alternatus $\left(10 \mathrm{~min}\right.$. or $20 \mathrm{~min}$.) followed by addition of the citrated human plasma at $37^{\circ} \mathrm{C}$ and timing. (D) Previous incubation of different volumes of essential oil from M. viridis with B. alternatus (10 min. or 20 min.) followed by addition of the citrated human plasma at $37^{\circ} \mathrm{C}$ and timing. ${ }^{*}$ Differ from positive control at $5 \%$.

and standard derivation of analyses done in triplicate. ${ }^{*}$ Differ statistically from the positive control at $5 \%$ of significance.

Essential oils components in the evaluated conditions did not interfere in electrophoretic migration profile in polyacrylamide gel of main classes of proteins (phospholipases $\mathrm{A}_{2}$ and proteases) present in the venoms (data not shown). However, fibrinogenolytic activity induced by B. moojeni venom was completely inhibited by M. pulegium oil in two volumes and incubation times evaluated (Fig. 2A). This essential oil was also effective in protecting fibrinogen molecules against the action of denaturing agents ( $\beta$-mercaptoethanol and sodium dodecyl sulphate) used during samples preparation for electrophoretic run, since at the end of electrophoresis run it was observed a profile of protein bands with molecular weight greater than the alpha, beta and gamma chains of fibrinogen, probably corresponding to intact fibrinogen molecules (Fig. 2B). 
TABLE 2

Effect of essential oils from Mentha pulegium and Mentha viridis on azocaseinolytic activity, induced by snake venoms, in solid medium

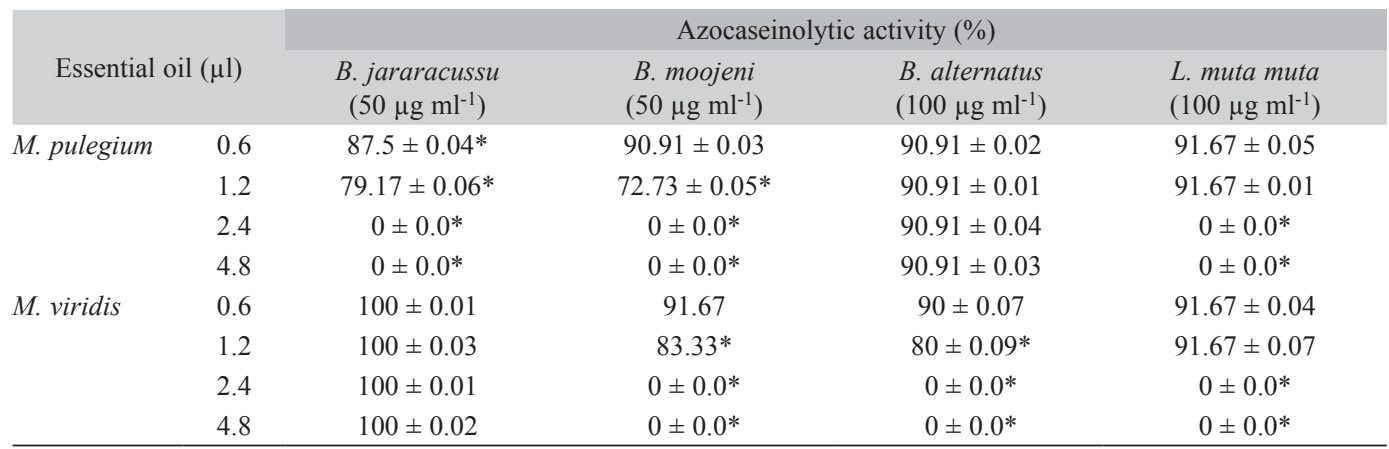

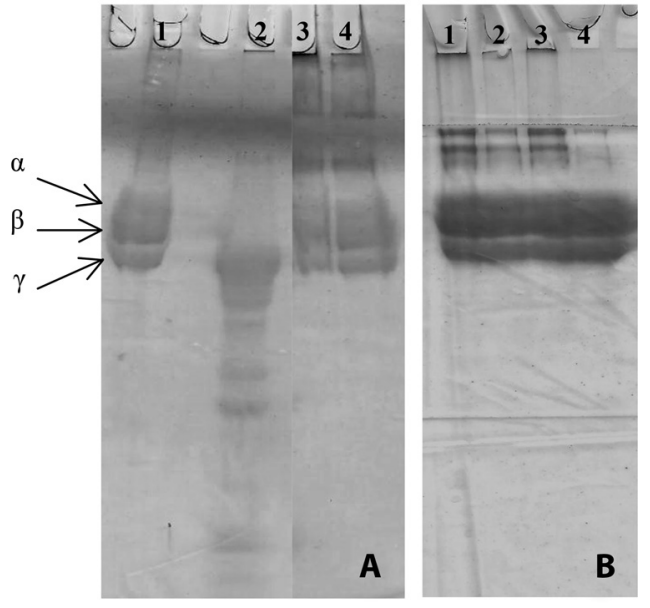

Fig. 2. Polyacrylamide gel electrophoresis in the presence of SDS to visualize the effect of the essential oils on the fibrinogenolytic activity induced by venoms. Samples: (A) 1-Fibrinogen $(60 \mu \mathrm{g})$; 2- Fibrinogen + B. moojeni $(40 \mu \mathrm{g})$; 3- Fibrinogen $+M$. pulegium $(0.6 \mu \mathrm{L})(15 \mathrm{~min}$ incubation $)$ + B. moojeni; 4- Fibrinogen + M. pulegium $(0.6 \mu \mathrm{L})(30 \mathrm{~min}$ incubation) + B. moojeni. (B) 1- Fibrinogen + M. pulegium $(0.6 \mu \mathrm{L})(30 \mathrm{~min}$ incubation); 3- Fibrinogen + M. pulegium $(0,6 \mu \mathrm{L})(15 \mathrm{~min}$ incubation); 3- Fibrinogen + M. pulegium $(0.6 \mu \mathrm{L})(5 \mathrm{~min}$ incubation); 4- Fibrinogen $(60 \mu \mathrm{g})$.

\section{DISCUSSION}

Chemical composition of $M$. pulegium and $M$. viridis essential oils were previously described by Silva et al., (2015). The majority constituents, identified by gas chromatography coupled to mass spectrometry (GC-MS) were pulegone $(50.01 \%)$, menthol $(31.90 \%)$ and menthone $(16.56 \%)$ for M. pulegium and linalool $(40.70 \%)$, carvone $(13.52 \%)$ and $\alpha$-terpinene $(8.56 \%)$ for $M$. viridis.

Data observed in clotting test suggests that there are interactions between constituents of the oils and enzymes, mainly coagulant proteases (fibrinogenolytics), present in the venom evaluated. The fact that the $0.15 \mu \mathrm{l}$ and 0.3 $\mu \mathrm{l}$ volumes of $M$. pulegium oil have induced similar coagulation times (Fig. 1C) highlights the concomitant action between specific interaction mechanisms and the sequestration of enzymatic ionic cofactors, the latter being widely described for several compounds of secondary metabolism (Havsteen, 1983; Santos \& Melo, 2007).

The results obtained in the present work show that the oil volume as well as the time and the incubation procedure are related to different forms of interactions between molecules present in the reaction medium. This suggests that essential oils interact with venom constituents, and with plasma components. They may act to protect blood molecules against the action of toxins or as enzyme inhibitors or enhancers, interacting directly with the toxins.

Miranda et al. (2014) described assays with rhizome and leaves essential oils from Hedychium coronarium in which the authors preincubated these oils with $B$. moojeni venoms 
before the addition of plasma. The data obtained by these authors corroborate the results found in the present work, whose inhibitory effect on coagulation induced by the venom is evidenced when the oils are submitted to presence of venoms before addition of plasma. It suggests interactions between terpene compounds from essential oils and proteins, mainly thrombinlike, present in venoms, responsible for the coagulant action.

A study revealed that anethole isolated from Foeniculum vulgare essential oil, inhibits clot retraction and platelet aggregation to a greater extent than the essential oil from which it is extracted, suggesting that the anticoagulant action present in the essential oil of Foeniculum vulgare is due to the presence of anethole (Tognolini et al., 2007).

The most widely used anticoagulant is heparin. However, because it has animal origin, it can induce diseases in mammals such as avian influenza and bovine spongiform encephalopathy (Mendes et al., 2008), reinforcing the need to find new anticoagulants and antithrombotic agents from plants.

Mentha viridis and $M$. pulegium essential oils promoted changes in coagulation time of citrated human plasma. Possible interactions of the constituents of the oils with human proteins that participate in blood coagulation cascade must be considered. It was also confirmed the induction between the constituents of the oils and proteases present in the venom. However, the interactions between these different molecules need to be better investigated, since in the proteolysis tests we could observe both potentiating and inhibitory action.

In the snake venoms from Bothrops and Lachesis genus, the proteolytic enzymes are the main responsible for the clinical manifestations observed in the accidents (Fonseca, 2010). Borges et al. (2001) verified the ability of Casearia sylvestris plant extracts in inhibiting proteases present in several Bothrops venoms. Anti-ophidian properties of Pentaclethra macroloba (Fabaceae) aqueous extract were also evaluated and this extract exhibited total inhibition of hemorrhagic and nucleolytic activities induced by different venoms (Silva et al., 2005). Natural inhibitors of protease generally act by competing with enzyme substrates binding to active site of enzymes (Costa et al., 2010).

The fibrinogenolytic assay allows evaluating the action of proteases and their inhibitors on the proteolysis of fibrinogen molecules. Proteases present in the venoms from Bothrops genus generally induces a proteolytic action on $\alpha$-chains of fibrinogen molecules, not being very effective in degrading $\beta$-chains and without action on $\gamma$-chain (Silva et al., 2012; Torres et al., 2012).

Considering the varied essential oils composition, it is possible to suggest that metal ion chelating molecules, substances with a hydrophobic character capable of modifying the reaction environment fluidity, or even to interact with toxin sites, acted in a peculiar way that justify the results obtained in fibrinogenolytic activity.

The rhizomes and leaves essential oils from $H$. coronarium did not show any proteolytic effect on fibrinogen (Miranda et al., 2014), corroborating with the results obtained in the present study with $M$. viridis and $M$. pulegium essential oils. Miranda et al. (2014) also described that essential oils were unable to inhibit fibrinogenolysis induced by L. muta muta, B. moojeni and B. atrox venoms at the same conditions (preincubation of venoms or fibrinogen for $30 \mathrm{~min}$ at $37^{\circ} \mathrm{C}$ with oil volumes of 0.6 and $1.2 \mu \mathrm{l})$.

Therefore, terpenes and phenylpropanoids that make up the complex mixtures defined as essential oils, found in varying amounts and structures, are responsible for several pharmacological and toxic effects (Miranda et al., 2014). Their wide characterization is made necessary so that they can be used in products intended for human consumption in an effective and safe manner.

In conclusion, the present study presented relevant information since it evaluated different venoms, oils with different compositions and volumes, and distinct substrates. Further studies are needed to provide information on the mechanisms of action of essential oils on 
venom proteins and on the possible forms of interaction between their constituents and fibrinogen molecules.

Ethical statement: authors declare that they all agree with this publication and made significant contributions; that there is no conflict of interest of any kind; and that we followed all pertinent ethical and legal procedures and requirements. All financial sources are fully and clearly stated in the acknowledgements section. A signed document has been filed in the journal archives.

\section{ACKNOWLEDGMENTS}

This work was supported CNPq, CAPES and FAPEMIG. The authors express their gratitude to Federal University of Lavras for the support structural and logistic to the researchers.

\section{RESUMEN}

Inhibición por aceites esenciales de Mentha viridis y Mentha pulegium (Lamiaceae) de la proteólisis, fibrinogenólisis y coagulación causada por venenos de serpientes. Los venenos de serpientes son ampliamente utilizados como herramientas de laboratorio para estudios de mecanismos fisiológicos, farmacéuticos y toxicológicos. Los venenos son recursos ricos en diferentes clases de proteasas que actúan sobre los factores de la cascada de coagulación, fibrinogenólisis y fibrinólisis, alterando los procesos homeostáticos y las fosfolipasas $\mathrm{A}_{2}$, los cuales están involucrados en procesos inflamatorios y de coagulación. Los productos naturales como los aceites esenciales se componen de ingredientes activos de amplia aplicación en las industrias alimentaria, farmacéutica y cosmética. El presente estudio evalúa los aceites esenciales de Mentha viridis y Mentha pulegium sobre la coagulación, fibrinogenólisis y degradación de azocaseína, inducida por los venenos de Bothrops sp. y Lachesis muta muta. Los aceites esenciales fueron obtenidos por hidrodestilación y sus componentes principales fueron identificados respectivamente como el linalool (40.70\%), carvona (13.52\%) y $\alpha$-terpineno (8.56\%); pulegone (50.01\%), mentol (31.9 $\%$ y mentona $(15.56 \%)$. Los aceites esenciales fueron previamente incubados con veneno de Bothrops alternatus, durante dos tiempos diferentes, luego se agregó el plasma y fue registrado el tiempo. El aceite de $M$. viridis presentó el más grande potencial anticoagulante. Mientras tanto, el aceite de $M$. pulegium presentó actividad anticoagulante o procoagulante dependiendo de la dosis evaluada. El tiempo de incubación también influyó en el efecto de los aceites sobre el tiempo de coagulación. En el ensayo azocaseínolitico, el aceite de M. pulegium redujo la actividad para todos los venenos evaluados. La inhibición más alta inducida para el veneno de B. jararacussu fue de $39.99 \%$, para M. viridis la actividad fue reducida en $57.72 \%$, mientras que para $B$. moojeni, la mayor inhibición observada fue de $74.67 \%$. La fibrinogenólisis inducida por el veneno de $B$. moojeni fue totalmente inhibida por ambos aceites en las proporciones evaluadas. Los resultados muestran la presencia de inhibidores de proteasas en los aceites, como las serinas y metaloproteasas (actuando sobre los factores de coagulación o sobre la actividad hemorrágica), como también fosfolipasas $\mathrm{A}_{2}$ (enzimas involucradas en los procesos de inflamación y coagulación), los cuales son inhibidores de amplia aplicación en áreas médicas y biotecnológicas.

Palabras clave: Bothropos; Lachesis; inhibición de proteasa; aceite esencial; compuestos naturales; propiedades antiofídicas.

\section{REFERENCES}

Agência Nacional de Vigilância Sanitária (ANVISA). (2010). Farmacopeia Brasileira (5rd ed). Brasília, Brasil: Anvisa.

Bakkali, F., Averbeck, S., Averbeck, D., \& Idaomar, M. (2008). Biological effects of essential oils. Food and Chemical Toxicology, 46, 446-475.

Baldo, C., Ferreira, M. J., Lopes, D. S., Izidoro, L. F. M., Ferro, E. A. V., Hamaguchi, A., \& Rodrigues, V. M. (2010). Action of neuwiedase, a metalloproteinase isolated from Bothrops neuwiedi venom, on skeletal muscle: an ultra structural and immunocytochemistry study. Journal of Venomous Animals and Toxins including Tropical Diseases, 16, 462-469.

Bandoni, A. L., \& Czepak, M. P. (2008). Os recursos vegetais aromáticos no Brasil: seu aproveitamento industrial para a produção de aromas e sabores. Vitória, Brazil: EDUFES Publisher.

Bernardoni, J. L., Sousa, L. F., Wermelinger, L. S., Lopes, A. S., Prezoto, B. C., Serrano, S. M., Zingale, R. B., \& Moura-da-Silva, A. M. (2014). Functional variability of snake venom metalloproteinases: Adaptive advantages in targeting different prey and implications for human envenomation. Plos One, 9, 1-13.

Borges, M. H., Soares, A. M., Rodrigues, V. M., Oliveira, F., Fransheschi, A. M., Rucavado, A., ... Homsi-Brandeburgo, M. I. (2001). Neutralization of proteases from Bothrops snake venoms by the aqueous extract from Casearia sylvestris (Flacourtiaceae). Toxicon, 39, 1863-1869.

Carvalho, B. M. A., Santos, J. D. L., Xavier, B. M., Almeida, J. R., Resende, L. M., Martins, W., ... 
Marchi-Salvador, D. P. (2013). Snake venom PLA 2 inhibitors isolated from Brazilian plants: Synthetic and natural molecules. BioMed Research International, 2013, 1-8.

Costa, J. O., Fonseca, K. C., Garrote-Filho, M. S., Cunha, C. C., Freitas, M. V., Silva, H. S., ... de Oliveira, F. (2010). Structural and functional comparison of proteolytic enzymes from plant latex and snake venoms. Biochimie, 92, 1760-1765.

Dimitri, M. J. (1980). Enciclopédia Argentina de Agricultura e Jardineira. Argentina: ACME Publisher.

Escalante, T., Rucavado, A., Fox, J. W., \& Gutiérrez, J. M. (2011). Key events in microvascular damage induced by snake venom hemorrhagic metalloproteinases. Journal of Proteomics, 74, 1781-1794.

Estêvão-Costa, M. I., Diniz, C. R., Magalhães, A., Markland, F. S., \& Sanchez, E. F. (2000). Action of metalloproteinases mutalysin I and II on several components of the hemostatic and fibrinolytic systems. Thrombosis Research, 99, 363-376.

Fonseca, K. C. (2010). Purificação e caracterização bioquímica da moozincina, uma metaloprotease dependente de zinco presente na peçonha da serpente Bothrops moojeni (caiçaca) (Master dissertation). Universidade Federal de Uberlândia, Brasil, Minas Gerais.

Guimarães, C. L. S., Moreira-Dill, L. S., Fernandes, R. S., Costa, T. R., Hamelin, L., Marcussi, S., ... Stabeli, R. G. (2014). Biodiversity as a source of bioactive compounds against snakebites. Current Medicinal Chemistry, 21, 2952-2979.

Gutiérrez, J. M., Avila, C., Rojas, E., \& Cerdas, L. (1988) An alternative in vitro method for testing the potency of the polyvalent antivenom produced in Costa Rica. Toxicon, 26, 411-413.

Gutiérrez, J. M., \& Rucavado, A. (2000). Snake venom metalloproteinases: their role in the pathogenesis of local tissue damage. Biochimie, 82, 841-850.

Havsteen, B. (1983). Flavonoids, a class of natural products of high pharmacological potency. Biochemical Pharmacology, 32, 1141-1148.

Khanuja, S. P. S., Shasany, A. K., Srivastava, A., \& Kumar, S. (2000). Assessment of genetic relationships in Mentha species. Euphytica, 111, 121-125.

Marcussi, S., Sant' ana, C. D., Oliveira, C. Z., Rueda, A Q., Menaldo, D. L., Beleboni, R. O., ... Soares, A. M. (2007). Snake venom phospholipases $A_{2}$ inhibitors: Medicinal chemistry and therapeutic potential. Current Topics in Medicinal Chemistry, 7, 743-756.

Markland, F. S. (1998). Snake venoms and the hemostatic system. Toxicon, 36, 1749-1800.
Matsui, T., Fujimura, Y., \& Titani, K. (2000). Snake venom proteases affecting hemostasis and thrombosis. Biochimica et Biophysica Acta (BBA) - Protein Structure and Molecular Enzymology, 1477, 146-156.

McCleary, R. J. R., \& Kini, R. M. (2013). Non-enzymatic proteins from snake venoms: A gold mine of pharmacological tools and drug leads. Toxicon, 62, 56-74.

Mendes, M. M., Oliveira, C. F., Lopes, D. S., Vale, L. H. F., Alcântara, T. M., Izidoro, L. F., ... Rodrigues, V. M. (2008). Anti-snake venom properties of Schizolobium parahyba (Caesalpinoideae) aqueous leaves extract. Phytotherapy Research, 22, 859-866.

Miranda, C. A. S. F., Cardoso, M. G., Mansanares, M. E., Gomes, M. S., \& Marcussi, S. (2014). Preliminary assessment of Hedychium coronarium essential oil on fibrinogenolytic and coagulant activity induced by Bothrops and Lachesis snake venoms. Journal of Venomous Animals and Toxins including Tropical Diseases, 20, 1-8.

Mourão, P. A. S., Pereira, M. S., Pavão, M. S. G., Mulloy, B., Tollefsen, D., Mowinckel, M. C., \& Abildgaard, U. (1996). Structure and anticoagulant activity of a fucosilated chondroitin sulfate from echinoderm: sulfated fucose branches on the polysaccharide account for its high antithrombotic action. Journal of Biological Chemistry, 271, 23973-23984.

Oliveira, C. H., Simão, A. A., Trento, M. V., César, P. H., \& Marcussi, S. (2016). Inhibition of proteases and phospholipases A2 from Bothrops atrox and Crotalus durissus terrificus snake venoms by ascorbic acid, vitamin E, and B-complex vitamins. Anais da Academia Brasileira de Ciências, 88, 2005-2016.

R Core Team. (2012). R: A Language and Environment for Statistical Computing. R Foundation for Statistical Computing. Vienna, Austria. Retrieved from https:// www.R-project.org

Sajevic, T., Leonardi, A., \& Krizaj, I. (2011). Haemostatically active proteins in snake venoms. Toxicon, 57 , 627-645.

Santos, S. C., \& Melo, J. C. (2007). Taninos. In C. M. O. Simões, E. P. Schenkel, G. Gosmann, J. C. P. Mello, L. A. Mentz, \& P. R. Petrovick (Eds), Farmacognosia: da planta ao medicamento (6th ed). Florianópolis, Brasil: Editora da UFSC.

Santos, V. M. C. S., Schneider, T. R., Bizzo, H. R., \& Deschamps, C. (2012). Alternativas de propagação na produção de óleo essencial de Mentha canadensis L. no Litoral Norte Catarinense. Revista Brasileira de Plantas Medicinais, 14, 97-102.

Sharon, D. Q., Trabi, M., \& Richards, R. S. (2016). Characterization and structural analysis of a potent anticoagulant phospholipase $\mathrm{A}_{2}$ from Pseudechis australis snake venom. Toxicon, 111, 37-49. 
Silva, L. O., Coppede, J. S., Fernandes, V. C., Sant'ana, C. D., Ticli, F. K., Mazzi, M. V., ... Sampaio, S. V. (2005). Antihemorrhagic, antinucleolytic and other antiophidian properties of the aqueous extract from Pentaclethra macroloba. Journal of Ethnopharmacology, 100, 145-152.

Silva, M. L., Marcussi, S., Fernandes, R. S., Pereira, P. S., Januário, A. H., França, S. C., ... Lourenço, M. V. (2012). Anti-snake venom activities of extracts and fractions from call us cultures of Sapindus saponaria. Pharmaceutical Biology, 50, 366-375.

Silva, L. F., Cardoso, M. G., Batista, L. R., Gomes, M. S., Rodrigues, L. M. A., Rezende, D. A. C. S., Teixeira, M. L., Carvalho, M. S. S., Santiago, J. A., \& Nelson, D. L. (2015). Chemical characterization, antibacterial and antioxidant activities of essential oils of Mentha viridis L. and Mentha pulegium L. American Journal of Plant Sciences, 6, 666-675.

Simões, C. M. O., Schenkel, E. P., Gosmann, G., Mello, J. C. P., Mentz, L. A., \& Petrovick, P. R. (2007). Farmacognosia: da planta ao medicamento. Florianópolis: Editora da UFSC.
Takeda, S., Takeya, H., \& Iwanaga, S. (2012). Snake venom metalloproteinases: Structure, function and relevance to the mammalian ADAM/ADAMTS family proteins. Biochimica et Biophysica Acta Proteins Proteomics, 1824, 164-176.

Tognolini, M., Ballabeni, V., Bertoni, S., Bruni, R., Impicciatore, M., \& Barocelli, E. (2007). Protective effect of Foeniculum vulgare essential oil and anethole in an experimental model of thrombosis. Pharmacology Research, 56, 254-260.

Torres, A. M., Camargo, F. J., Ricciardi, G. A., Ricciardi, A. I., \& Dellacassa, E. (2012). Neutralizing effects of Nectandra angustifolia extracts against Bothrops neuwiedi snake venom. Natural Product Communications, 6, 1393-1396.

Wang, H. T., Yu, X., Liu, Y., Liang, C. Y., \& Li, W. L. (2013). Analysis of genetic variability and relationships among Mentha L. using the limonene synthase gene, LS. Gene, 524, 246-252. 